\title{
Snail fauna of the oldest cemeteries from Riga (Latvia)
}

\author{
Jozef ŠTeFFek ${ }^{1}$, Arturs StalažS $^{2} \&$ Edgars DreiJers ${ }^{3}$ \\ ${ }^{1}$ Faculty of Ecology and Environmental Science, Technical University of Zvolen, Institute of Forest Ecology, \\ Slovak Academy of Sciences, Stúrova 2, SK-960 53 Zvolen, SlovakRepublic; e-mail:steffekjozef@yahoo.com \\ ${ }^{2}$ Latvia State Institute of Fruit-Growing, Graudu iela 1, Dobele, Dobeles nov. (Dobeles raj.), LV-3701, Latvia, \\ e-mail: arturs.stalazs@lvai.lv \\ ${ }^{3}$ University of Latvia, Faculty of Biology, Kronvalda bulvāris 4, Rīga, LV-1010,Latvia; e-mail: helix@inbox.lv
}

Šteffer J., Stalažs A. \& Dreijers E., 2008: Snail fauna of the oldest cemeteries from Riga (Latvia). - Malacologica Bohemoslovaca, 7: 79-80. Online serial at $<$ http://mollusca.sav.sk> 29-Sep-2008

\begin{abstract}
We report on the snail fauna from one of the oldest cemeteries from Riga city (Latvia), viz. Lielie kapi and Pokrova kapi. A list of all the snail species recorded from both cemeteries and limited information on the biotope conditions are given. Cecilioides acicula (O.F. Müller, 1774) is first recorded from Latvia and was found at a grassland within the tomb area of the Pokrova kapi cemetery.
\end{abstract}

Key words: Molluscs, land snail, cemeteries, Cecilioides acicula, Riga, Latvia

\section{Introduction}

Historical cemeteries represent a suitable refuge for snail fauna within an urban area. Their positive influence is mainly due to dense plant and tree (Tilia sp., Acer sp., Fraxinus sp.) cover which form favourable microclimatic and soil conditions. Yet, such biotopes, due to the introduction of exotic plants, also serve as potential vectors for biological invasions of foreign snail and slug species. In this paper, we present a checklist of the snail fauna of two historical cemeteries, viz. Lielie kapi (Grate Cemetery) and Pokrova kapi (Pokrow's Cemetery), in the urban area of Riga, Latvia $\left(50^{\circ} 85^{\prime} \mathrm{N}, 63^{\circ} 13^{\prime} \mathrm{E}\right)$.

\section{Study area}

The history of the cemetery of Lielie kapi starts from 1773. Originally, until the $18^{\text {th }}$ century, the area was a sandy field. Nowadays, Lielie kapi is a monumental park with many walls, monuments and a few chapels. It was closed as an active cemetery in 1969, and was later transformed to a monumental park. The Pokrova kapi is still in use. Parts of Lielie kapi and Pokrova kapi are separated from the major area of Lielie kapi by the Senču Street. The detached parts of both cemeteries differ from the larger part in a higher cover of shrubs and trees.

The dominant tree species at both cemeteries are lime (Tilia sp.), maple (Acer sp.) and oak (Quercus sp.) together with less abundant Betula, Aesculus and several Populus, Fraxinus and Thuja trees. Most of the trees have been planted artificially. The dense tree canopy forms dark conditions at both cemeteries, especially at the Pokrova kapi cemetery that has a dense understory of small trees. The herbal layer is dominated by the nitrophilous species $A e$ - gopodium podagraria, Urtica dioica and Lamium album. Regular grass cutting is applied in the largest part of the Lielie kapi cemetery.

During the Baltic malacozoological conference, held on the September $21^{\text {st }}-24^{\text {th }} 2006$ in Riga, authors visited the area of cemeteries Lielie kapi and Pokrova kapi. We sampled the (decaying) leaf litter layer at several sites, which were searched for the presence of snails.

\section{Results and discussion}

A total of 17 mollusk species was recorded at both cemeteries (Table 1). The highest species richness was recorded at the Pokrova kapi cemetery and in the vicinity of building walls (15 species). The open grassland with intensive grass-cutting were rather poor in recorded species (six species). Two land snail species were abundant in this area, viz. Arianta arbustorum and Trichia hispida. A high density of the introduced, and invasive, species Krynickillus melanocephalus, which is regularly found in the urban area of Riga city, was not found in the study area. This may be caused by the very dry weather conditions during the months before sampling.

Cecilioides acicula (O.F. Müller, 1774) is first recorded from Latvia. The geographical range of C. acicula is the W Palaearctic and Central Mediterranean where it can be found in low- as well as upland. This species lives subterraneous. It has been recorded across Europe, common also in the southern part of Scandinavia and in Great Britain (Kerney et al. 1983, WikTor 2004). Until now, the species was not known from Latvia (RudzīTe et al. 1996, 1997, RudzīTe 2000). In Riga, it was found together with the Caucasian slug Krynickillus melanocephalus 
Table 1. Snail species found in cemateries Lielie kapi and Pokrova kapi (Riga City, Latvia), C1 - Pokrova kapi and Lielie kapi (smaller part), C2 - Lielie kapi (larger part).

\begin{tabular}{|l|c|c|l|}
\hline Species & C1 & C2 & Comments \\
\hline Arianta arbustorum (Linnaeus, 1758) & + & + & \\
\hline Arion (Carinarion) sp. juv. & + & + & \\
\hline Arion silvaticus Lohmander, 1937 & + & + & \\
\hline Cecilioides acicula (O.F. Müller, 1774) & + & + & new for Latvia \\
\hline Cochlicopa lubrica (O.F. Müller, 1774) & + & + & \\
\hline Cochlodina laminata (Montagu, 1803) & + & - & \\
\hline Deroceras reticulatum (O.F. Müller, 1774) & + & + & \\
\hline Discus ruderatus (W. Hartmann, 1821) & + & - & \\
\hline Helix pomatia Linnaeus, 1758 & - & + & non-native \\
\hline Krynickillus melanocephalus Kaleniczenko, 1851 & + & + & non-native \\
\hline Limax maximus Linnaeus, 1758 & + & - & non-native \\
\hline Oxychilus draparnaudi (H. Beck, 1837) & + & + & non-native \\
\hline Oxychilus translucidus (Mortillet, 1881) & - & + & non-native \\
\hline Succinea putris (Linnaeus, 1758) & + & - & \\
\hline Trichia hispida (Linnaeus, 1758) & + & + & \\
\hline Vallonia costata (O.F. Müller, 1774) & + & + & \\
\hline Vallonia pulchella (O.F. Müller, 1774) & + & + & \\
\hline Total 17 sp. & & & \\
\hline
\end{tabular}

Explanatory notes: + species present, - species absent

Kaleniczenko, 1851 and Oxychilus translucidus (Mortillet, 1853) on a grassland within the tomb area in the Pokrova kapi cemetery (10 shells leg., det. et coll. J. Šteffek, 24 Sep 2006). K. melanocephalus was found for the first time by A. Stalažs in 1997 in the National Botanical Gardens of Latvia (Salaspils, Riga district). The species was only recognized in 2000 after dissection by E. Dreijers and A. Wiktor. The first record of O. translucidus is from 1999 from greenhouses of the National Botanical Gardens of Latvia (Leg. A. Stalažs) and was identified by anatomical dissection by E. Dreijers after 2000 (E. Dreijers \& A. Stalažs, unpubl. data). Both species belong to alien molluscs and $K$. melanocephalus appears to be an invasive species, which is known from several localities in Hungary, Bulgaria, Turkey, Poland and Israel (WIKTOR 2004), Latvia (Dreijers 2003) and Germany (Meng \& Bössneck 1999, Bössneck \& Feldmann 2003).

In the Baltic States, O. translucidus is one of the three alien species from the genus Oxychilus (O. cellarius, O. draparnaudi and $O$. translucidus) and the species occurs in Latvia (several localities) and Lithuania (one record from Kaunas by A. Stalažs in 2003). Only O. alliarius (Miller, 1822 ) is a native species in the Baltic States (E. DreIJERS \& A. Stalažs, unpubl. data).

\section{Acknowledgements}

The study was funded by research grants no. 1/3283/06, 2/6007/26 and 2/5152/25 of the Slovak Grant Agency for Science (VEGA).

\section{References}

BössneCK U. \& Feldmann A., 2003: Zur Ausbreitung von Neozoa im Stadtgebiet von Erfurt am Beispiel der Landschnecken Cernuella neglecta (Draparnaud, 1805), Monacha cartusiana (O.F. Müller, 1774) and Krynickillus melanocephalus Kaleniczenko, 1851 (Mollusca: Gastropoda). - Veröffentlichungen Naturkundemuseum Erfurt, 22: 115-125.

DreiJers E., 2003: A history of the investigation and fauna of the slugs (Gastropoda terrestria nuda) of Latvia, p. 33. - In: Second International Conference „Research and conservation of biological diversity in Baltic Region", book of Abstracts, Daugavpils. 24.-26.04.2003.

Kereny M.P., Cameron R.A.D. \& Jungbluth J.H., 1983: Die Landschnecken Nord- und Mitteleuropas. - Verlag Paul Parey, Hamburg/Berlin.

Meng S. \& Bössneck U., 1999: Krynickillus melanocephalus Kaleniczenko, 1851 in Deutschland eingeschleppt (Gastropoda: Stylomatophora: Agriolimacidae). - Malk. Abh. Mus. Tirkde. Dresden Bd., 19: 304-309.

Rudzite M., 2000: Mācies pazīt - Latvijas zemesgliemeži. - Riga, 147 pp.

Rudzite M., Pilate D. \& Parele E., 1996: Latvija sastopamo gliemju sugu latviskie nosaukumi. - Daba un Muzejs, 6: 85-92.

Rudzite M., Pilate D. \& Parele E., 1997: Molluskenfauna Lettlands. Liste der in Lettland vorkommenden Molluskenarten (Gastropoda, Bivalvia). - Mitt. Dtsch. malakozool. Ges., 59: $1-10$.

Schlesch H., 1942: Die Land- und Süsswassermollusken Lettlands. - Korresponenzblatt des Naturforscher-Verein zu Riga, 64, $311 \mathrm{pp}$.

Wiktor A., 2004: Ślimaki lądowe Polski. - Wydawnictwo Mantis, Olsztyn, 302 pp. 